\title{
Attitudes of Female Students Specializing in Autism Spectrum disorders towards Voluntary Work Programs at the University of Jeddah in the Kingdom of Saudi Arabia
}

\author{
Alham Mustafa Houran Al-Qusayreen ${ }^{1}$ \\ Associate Professor, Department of Special Education, University of Jeddah \\ dr.alham_2013@yahoo.com
}

Received: $28^{\text {th }}$ Sept 2020 Revised: $18^{\text {th }}$ Oct 2020 Accepted: $16^{\text {th }}$ Nov 2020 DOI: https://doi.org/10.31559/CCSE2020.1.2.4

Abstract: The study aimed to examine the attitudes of female students specializing in Autism Spectrum disorders towards voluntary work programs at the University of Jeddah. The sample consisted of 152 female students majoring in Autism Spectrum disorders in the Department of Special Education at the University of Jeddah. researcher used the Descriptive analytical survey method and a scale of (32) items. The validity and reliability of the instrument was verified. The results showed no statistically significant differences at the level of $(\alpha=0.05)$ in the means of the attitudes of the students majoring Autism Spectrum disorders towards voluntary work programs at the University of Jeddah, based on the variable of the social status, the academic level, and the student's social status at the level of the scale as a whole and at the level of its sub-dimensions. Among the most important recommendations are the establishment of special units for voluntary work in the College of Education for Girls and holding educational courses dealing with volunteering.

Keywords: Voluntary work; Autism Spectrum Disorder; female students at University of Jeddah; attitudes.

${ }^{1}$ Corresponding author

Alham Mustafa Houran Al-Qusayreen

Associate Professor, Department of Special Education, University of Jeddah

E-mail: dr.alham_2013@yahoo.com 


\section{Introduction}

Volunteer work has been associated with the meanings of good work and Humanity work, a social phenomenon that has existed throughout the ages from the beginning of creation to the present, and its forms, fields and performance vary according to the directions of society, traditions and religious beliefs of each society. Social work is a key factor in building society and spreading social cohesion among the members of society. Voluntary work is a Humanity practice that has been closely linked to all the meanings of good and good work for all people since Since God created the earth and the human and beings on it (Zahrani, 2003:12).

Universities are one of the most important institutions that spread the culture of volunteerism, promote the concept of volunteering, and make it a community culture because it is the largest human vessel in terms of culture. based on science if it is consolidating volunteer work.

The youth are the arms of development in any country and they are the main guarantee for its continuation, namely renewable energy and the main engine of work and achievement in various types of Albashery societies, and the most important element in building the future and on their shoulders facing the challenges of the future, young women are the ones who have enthusiasm The desired and necessary rush and enlightened thinking, and one of the important roles in which young people play a role in their active participation in volunteer work, which has become necessary importance, and with the increasing interest in volunteering has doubled its importance and role in the progress of society, where volunteerism has become in our time The current situation is a principal column within the advancement of social orders.

Al-Bishri indicated in his study (2019) that volunteer work, "It is to provide assistance, aid and effort, In order to work to achieve experience in society in general and its members in particular, And he called it volunteer work Because a person does it voluntarily without being forced by others to do it, It is an inner will, And the conquest of the power of good over the side of evil, And evidence of a prosperous society, The greater the number of positive and constructive elements in a society -positive and constructive elements in a society that has led to its development and growth " (JohnWillson,2014).

Volunteering represents the highest features of social responsibility with its many levels and from the guidance of Islam and the religious and social status of 
International Journal of Childhood, Counselling, \& Special Education (CCSE), Volume1, Issue: 2, December: 2020, pp.161-184

volunteering, the vision of 2030 came to adopt this trend and benefit from it in the social and developmental role of volunteering, and indicated trends and interests International and international on the importance of volunteering, and instilling its culture among young people, to contribute to accelerating the wheel of development in several fields, and in investing in the times of youth, for what is useful in enhancing their belonging and developing their abilities and skills educational, practical, technical, and an opportunity for them to express their desires and inclinations And their interests (Darwish, 2015:369).

Saudi society has witnessed growth in all fields and change in the cultural aspect and a rapid social transformation reflected its effects on the behaviors and trends of society, and came the attention of Saudi Arabia towards the Saudi youth towards volunteer work and the political, social and development events surrounding it in all but the 2030 vision, one of its priorities was to focus on the kingdom's youth and make them an effective force and exploit their potential. Voluntary work reflects a positive image of society and shows how prosperous it is. Volunteering is every effort made by a person, whether mentally or physically, to achieve an interest or to increase an existing benefit without direct financial return in the public interest (Al-Harbi, 2000:543).

Kunda also noted in her study (2018)"That effective volunteering is a distinctive feature of modern societies, which is the prominent role played by the charitable institutions of the community, where it is a social mediator for development and the most appropriate tool that contributes to the achievement of cohesion and solidarity among the individuals of society, and has multiplied Views on the concept of volunteerism in terms of form but agreed in terms of substance and purpose." (Abu Al-Nasr, 2016, p.29:).

Motivations for volunteering:

Al-Nabulsi (2000:101) noted that volunteers differ in their goals, motivations and desires to volunteer, including:

- Volunteering for the love and assistance of others

- Volunteering to form social relationships

- Achieving oneself, defending values and spreading the principles that man believes in.

Areas of volunteering:

Volunteer work may include several useful and useful areas, studies have differed in their treatment of the fields of volunteering and their coverage of all aspects of Albashery life, and 
many studies such as the study (el beshry, 2019; Al Qahtani, 2019; Khaddam, 2016; Al-Mazin, 2013). It is referred to in several sections:

The social and cultural field: such as caring for orphans, children with disabilities, the elderly, family guidance, caring for juveniles, needy and poor families, cultural awareness.

- National area: homeland defense, scout camps, natural disasters life.

- Field of Education: Literacy, Continuing Education, Quran Memorization Workshops

Health field: holding seminars, guiding.

- The field of advocacy: inviting the community to the Islamic religion, supervising centers and associations, volunteering for pilgrims and hajj.

Forms of volunteering:

Divides volunteering into two forms

- Individual volunteer work: a behavior practiced by a member of the community on his own or with the participation of a group of his friends in which they do not wish for financial or moral benefits.

- Institutional volunteering: through the volunteering of the individual in one of the ngos, he is trained in supervising him and assigning him to tasks.

The study of Al Mutawa (2019) aimed to know the areas of volunteering and its educational dimensions in the vision of the Kingdom 2030, and the researcher used the descriptive curriculum, and the results showed the attention of vision to the pillars of community development and volunteer work and its fields and educational dimensions, and the results showed a rise in the frequency of promotion of identity Islamic and values, care for education and the culture of volunteering, increase opportunities for volunteering and promote authenticity and national belonging.

Al-Qahtani also pointed out his study (2019) to learn about the reality of the department of volunteer work at Imam Mohammed Bin Saud Islamic University, and the researcher used the descriptive survey method as he used the questionnaire as a tool for study, and the sample of the study consisted of

(370) students of the Faculty of Social Sciences, and resulted in a number of results. The most important of these is that the evaluations of the reality of the department of volunteer work at Imam Mohammed Bin Saud Islamic University came to an average degree, and that there is agreement among the sample members of the study on the problems facing the 
management of volunteer work, and it was recommended to enroll students in programs for training volunteers before assigning them to work, And the need to establish certain management units by volunteering in the college.

In the Herntq study (2017) aimed to know the importance of volunteering for successful children and adults in literacy programs in American public libraries, the descriptive analytical method was used and reached a number of results, including: an expanded set of volunteer openings in American open libraries and is one of the foremost critical Programs in which volunteers work and volunteers who have decided to become literacy volunteers have similar reasons not to make the decision to volunteer because they love public libraries more than other places for volunteering and often have an educational background and have shown their medicine sought to Volunteer work at the library is remarkably passionate.

Al-Mazin (2016) conducted a think about pointed at recognizing the patterns of volunteer work in Palestinian universities in light of some variables, and the researcher used the descriptive curriculum, and the study community is from all students of Gaza universities and the sample was (309) students and the questionnaire was used and the study found that there are no differences Statistically significant among the averages of the study sample estimate of their attitudes towards volunteerism due to the variables of gender, specialization and university.

The study of Caroline and others (2014) aimed me to know the roles of volunteers, participation and voluntary commitment of sports organizations, to know the best fundamental differences of sports volunteers and how these differences are manifested through different roles and whether there are sufficient differences between volunteers. Basic and secondary, the survey method was used and the results showed that sports volunteering can help participate and commit to developing recruitment strategies designed to develop volunteer goals.

Al-Khaddam (2013) also revealed the trends of university youth towards volunteering: Ajloun University College as a model, and used the descriptive curriculum and designed a questionnaire distributed to a sample (300) students from Ajloun University College, and the study found that there are no statistically significant differences towards volunteer work Due to the variables of specialization, level of study and age.

In the Gege study (2013) aimed to identify the study of volunteers and obstacles of volunteering among university students and 
analyze the list of volunteer performance and models of enjoyment disabilities at the University of Pennsylvania and used the researcher's descriptive analytical method, and the sample of the study consisted of (340) students and used the questionnaire represented In four themes represented in the characteristics of volunteering, the scope of volunteering, the sectors of work, the type of participation and collected data at one of the Great American University of Southeast, the results determined that the majority were practicing volunteering in some capacities, and families and teachers were responsible for The introduction of the majority and organizations focusing on Albashery services were more important among the organizations volunteering, as well as the examination of many associations between motives and restrictions and discussion.

Al-Harsh and Jabr (2012) conducted a study aimed at identifying the trends of students specializing in social work at $\mathrm{Al}$ Quds University towards the volunteer program, and the sample consisted of (205) students, and the study aimed to identify the personality of the volunteer and his motives, towards voluntary institutions, and the impact of the changing sex, and the place of residence The results showed that volunteer work at Al-Quds University reaches a high degree and wide participation of students, and the interest in volunteering does not govern gender or place of residence.

The current study has agreed with previous studies on the subject of taking volunteer work as its subject, and also agreed on the study tool, the questionnaire. As a study (Albashry, 2019; Al-Qahtani, 2019; Khaddam, 2016; Al-Mazin, 2013).

The current study has benefited from previous studies from the theoretical training, and from the theoretical framework of questionnaires such as the study (AlMazin, 2013) and the study (AlHrash, 2012). The current study is in agreement with previous studies in terms of research curricula, and in terms of the study community, which is the university community. As a study (Albashry, 2019; AlQahtani, 2019; Hernán, 2017: AlMazin, 2013; Caroline and others, 2014: Gig, 2013: Al-Harsh and Jabr,2012).

The importance of research lies in identifying the trends of students specializing in ASD at Jeddah University towards volunteer programs by clarifying the necessity of volunteering and its importance to university youth, investing their time in noble work, and determining the importance of volunteering in the university community and highlighting His educational and religious status is 
addressed by a social dimension related to the life of students inside and outside the university and the degree of their interaction with the ocean.

Volunteer work is considered an important activity in the development of the community and its development, and consider it a religious, social and Albashery value that must be preserved, and the researcher has noted the relative absence of volunteer culture at Jeddah University, and not giving proper attention to the value of volunteer work in academic institutions as the participation of female students in volunteer work is still in the interest Individual and personal interest has not become a sign of the absence of a list of organizational and voluntary work, as indicated by the study (2019, AlQahtani), (Mahdi, 2019), (Al-Mazin, 2016), and Study (Al-Harsh,2012).

- The following questions emerged from the study problem:

1. What are the trends of female students specializing in ASD towards volunteer work programs at Jeddah University?

2. What is the impact of the Economic situation on the trends of female students specializing in ASD towards volunteering programs at Jeddah University?
3. What is the impact of the social situation on the attitudes of female students specializing in ASD towards volunteering programs at Jeddah University?

4. What is the effect of the scholastic level on the states of mind of female understudies specializing in ASD towards volunteer in programs at Jeddah University?

\section{Study methodology}

The researcher used the descriptive analytical survey method in this research. To reveal the trends of female students of the Autism Spectrum Disorder and Behavioral Disorders specialization towards volunteer work programs at the University of Jeddah, and identifying the most important obstacles and difficulties that prevent female students from enrolling in volunteer work programs at the University of Jeddah.

\section{Research Community}

The current research community of (217) students of all students specializing in ASD and, for the first semester 1440/1441 H, in the Department of Special Education at Jeddah University.

\section{Methods of data Analysis}

Sample search:

In order to achieve the goals 
of research in investigating the role of the university in promoting volunteer work among female students, the questionnaire prepared for this objective was distributed the sample of the research was randomly selected, and the research sample consisted of (154) students.

Research procedures Study tool:

Measure the trends of female students specializing in ASD towards volunteering programs at Jeddah University."

The primary section of the scale includes a letter from the researcher to the study sample to clarify its objectives, and emphasize the confidentiality of the data and the first part of the measure included the personal information of the understudy and factors (social status, scholarly level, financial status), whereas the moment segment incorporates a set of tomahawks separated into three segments: the individual introduction towards the person its thought processes are the center of the drift towards the nature of volunteerism, and the center of the slant towards the put of volunteerism.

The five-year Lykert ladder (strongly ok, ok, neutral, I don't agree, I don't strongly agree) was used to record the sample responses of the study on the scale, the scale was built in the current study using previous Arab and foreign studies related to the current study and attempted to use it as a study of ALkadam (2013) Al-Mazin (2016) and Mutawa (2019).

As well as looking at a few hypothetical writings on the subject of understudies with ASD, the scale is in its final form of (32) singles.

Check the virtual honesty of in this research tool in its initial form.

- Check signs of of trustworthiness and consistency of the search tool in its final form by applying it to a survey sample outside the sample of this research.

- Preparing the search tool electronically so that it is easy to reach the members of the sample due to its specificity and difficulty in communicating with them individually and personally, and then distributing the search tools to the members of the research sample after explaining the purpose of the study to them.

- Ask the individuals of the sample study to answer the paragraphs of the scale the study tools as they see them expressing their point of view in all honesty and objectivity. This is after they have been informed that their answer will only be used for scientific research purposes.

Collecting data and then entering it into computer memory, with a view to 
International Journal of Childhood, Counselling, \& Special Education (CCSE), Volume1, Issue: 2, December: 2020, pp.161-184

Table 1: The distribution of study sample members by variables (social status, economic status, academic level)

\begin{tabular}{lrrr}
\hline & Category & Iteration & Percentage\% \\
\hline Social status & Single & 125 & 81.17 \\
Economic situation & Married & 29 & 18.83 \\
& Average & 62 & 40.26 \\
Academic level & Excellent & 92 & 59.74 \\
& Level 6 and & 20 & 12.99 \\
below & 104 & 67.53 \\
Level 7 & 30 & 19.48 \\
& Level 8 & 154 & 100 \\
\hline
\end{tabular}

The sincerity and stability of the resolution:

The authenticity and stability of the resolution has been verified in several ways, including:

Indications of honesty and consistency to measure trends towards volunteering programs

First: Virtual honesty

The apparent honesty of the scale was verified by a group of experienced arbitrators specializing in the field of special education and educational sciences in the faculties of education in Saudi universities, which numbered

(8) arbitrators, as well as presented to (10) specialists of ASD, in order to express their opinions on Accuracy and validity of the content of the scale in terms of: the degree of measurement of the paragraph to the dimension, the clarity of the paragraphs, the language formulation, and its appropriateness to measure what it was set for, and the addition, modification or deletion of what they deem appropriate of the paragraphs.

In the light of the observations and opinions of the arbitrators reviewed after a meeting with a number of them, the proposed amendments were made to the paragraphs of the measure of trends towards volunteering programmers, bringing the number of paragraphs of the scale after arbitration (32) paragraphs.

Second: The sincerity of the building:

In order to verify the indicators of building credibility, the measure was applied to a survey sample of (25) students from outside the target study sample, and the building credibility indicators were calculated using Pearson correlation coefficient, to find the values of the paragraph-by-dimension correlation, 
International Journal of Childhood, Counselling, \& Special Education (CCSE), Volume1, Issue: 2, December: 2020, pp.161-184

\section{and the values of the paragraph degree. for the scale, as in table (2).} correlation coefficient in the overall

Table 2: Values of correlation coefficients between the paragraphs of the scale of trends towards volunteerism on the one hand and the overall degree of the scale and the dimensions that follow it on the other

\begin{tabular}{|c|c|c|c|c|}
\hline Domain & Number & Trends towards volunteerism & \multicolumn{2}{|c|}{ Association with } \\
\hline & & & Dimension & Total \\
\hline \multirow[t]{15}{*}{$\begin{array}{l}\text { The nature of } \\
\text { volunteering }\end{array}$} & 1 & $\begin{array}{l}\text { Volunteering institutions } \\
\text { contribute to deepening social } \\
\text { solidarity among members of } \\
\text { society. }\end{array}$ & $0.49^{*}$ & $0.42^{*}$ \\
\hline & 2 & $\begin{array}{c}\text { Planting Islamic principles and } \\
\text { values that encourage } \\
\text { volunteering. }\end{array}$ & $0.52 *$ & $0.47^{*}$ \\
\hline & 3 & $\begin{array}{l}\text { Using social mediato encourage } \\
\text { volunteerism. }\end{array}$ & $0.61^{*}$ & $0.55^{*}$ \\
\hline & 4 & $\begin{array}{l}\text { Study programs include the } \\
\text { concepts of volunteering. }\end{array}$ & $0.62^{*}$ & $0.41^{*}$ \\
\hline & 5 & $\begin{array}{l}\text { seminars on the importance of } \\
\text { volunteering and adopting and } \\
\text { refining the personality of the } \\
\text { university student. }\end{array}$ & $0.75^{*}$ & $0.61^{*}$ \\
\hline & 6 & $\begin{array}{l}\text { Community organizations adopt } \\
\text { effective volunteer programs. }\end{array}$ & $0.83^{*}$ & $0.69^{*}$ \\
\hline & 7 & $\begin{array}{c}\text { The volunteer communicates } \\
\text { with the foundation's staff on } \\
\text { an ongoing basis. }\end{array}$ & $0.88^{*}$ & $0.73^{*}$ \\
\hline & 8 & $\begin{array}{l}\text { I've received proper guidance } \\
\text { and guidance during } \\
\text { volunteering. }\end{array}$ & $0.87^{*}$ & $0.73^{*}$ \\
\hline & 9 & $\begin{array}{l}\text { It is important to volunteer, } \\
\text { including married students. } \\
\text { Volunteering allows }\end{array}$ & $0.69^{*}$ & $0.61^{*}$ \\
\hline & 10 & $\begin{array}{l}\text { opportunities for young } \\
\text { people to express themselves } \\
\text { and their energies. }\end{array}$ & $0.76^{*}$ & $0.51^{*}$ \\
\hline & 11 & $\begin{array}{l}\text { From the difficulties of } \\
\text { volunteering in relation to } \\
\text { society the economic, political } \\
\text { and social conditions. }\end{array}$ & $0.58^{*}$ & $0.53^{*}$ \\
\hline & 12 & $\begin{array}{l}\text { Volunteering does not require } \\
\text { expertise and specialization. } \\
\text { Volunteering is a heavy }\end{array}$ & $0.73^{*}$ & $0.31^{*}$ \\
\hline & 13 & burden. & $0.87^{*}$ & $0.54^{*}$ \\
\hline & 14 & $\begin{array}{l}\text { I encourage my classmates to } \\
\text { participate in volunteering. } \\
\text { Volunteering for young }\end{array}$ & $0.82^{*}$ & $0.54^{*}$ \\
\hline & 15 & $\begin{array}{l}\text { people brings multiple skills } \\
\text { and experiences. }\end{array}$ & $0.80^{*}$ & $0.65^{*}$ \\
\hline
\end{tabular}


International Journal of Childhood, Counselling, \& Special Education (CCSE), Volume1, Issue: 2, December: 2020, pp.161-184

\begin{tabular}{|c|c|c|c|c|}
\hline & 16 & $\begin{array}{l}\text { I feel like volunteering is a } \\
\text { waste of time. }\end{array}$ & $0.73^{*}$ & $0.64^{*}$ \\
\hline \multirow{9}{*}{$\begin{array}{c}\text { The individual's } \\
\text { personality and } \\
\text { motivations }\end{array}$} & 17 & $\begin{array}{l}\text { I feel Albashery when I help } \\
\text { others by volunteering. }\end{array}$ & $0.48^{*}$ & $0.43^{*}$ \\
\hline & 18 & $\begin{array}{l}\text { Volunteering refines and } \\
\text { develops my personality. }\end{array}$ & $0.79^{*}$ & $0.65^{*}$ \\
\hline & 19 & $\begin{array}{l}\text { Volunteering gives me the } \\
\text { opportunity to freely express } \\
\text { my opinions and ideas. }\end{array}$ & $0.76^{*}$ & $0.65^{*}$ \\
\hline & 20 & $\begin{array}{c}\text { Volunteering makes me } \\
\text { sympathize with the suffering } \\
\text { of others. }\end{array}$ & $0.78^{*}$ & $0.69^{*}$ \\
\hline & 21 & $\begin{array}{l}\text { Volunteering helps me } \\
\text { develop my professional } \\
\text { abilities in the future. }\end{array}$ & $0.45^{*}$ & $0.41^{*}$ \\
\hline & 22 & $\begin{array}{c}\text { I use my free time to } \\
\text { volunteer. }\end{array}$ & $0.70^{*}$ & $0.61^{*}$ \\
\hline & 23 & $\begin{array}{l}\text { Volunteering develops asense } \\
\text { of self and responsibility. }\end{array}$ & $0.67^{*}$ & $0.63^{*}$ \\
\hline & 24 & $\begin{array}{l}\text { Volunteering achieves } \\
\text { the satisfaction of an } \\
\text { individual's psychological } \\
\text { needs. }\end{array}$ & $0.61^{*}$ & $0.52^{*}$ \\
\hline & 25 & $\begin{array}{l}\text { I feel good when I find } \\
\text { appreciation as a result of my } \\
\text { volunteering efforts. }\end{array}$ & $0.46^{*}$ & $0.43^{*}$ \\
\hline The status & 26 & $\begin{array}{l}\text { Volunteering strengthens } \\
\text { feelings of belonging } \\
\text { and national and religious }\end{array}$ & $0.71^{*}$ & $0.60^{*}$ \\
\hline \multirow[t]{7}{*}{ Of volunteerism } & & $\begin{array}{c}\text { loyalty among university } \\
\text { youth. }\end{array}$ & & \\
\hline & 27 & $\begin{array}{l}\text { Volunteering for young } \\
\text { people achieves an important } \\
\text { skill in the ability to plan and } \\
\text { solve problems. }\end{array}$ & $0.74^{*}$ & $0.60^{*}$ \\
\hline & 28 & $\begin{array}{l}\text { Volunteering institutions } \\
\text { contribute to deepening } \\
\text { solidarity within society. }\end{array}$ & $0.69^{*}$ & $0.51^{*}$ \\
\hline & 29 & $\begin{array}{l}\text { Volunteering helps young } \\
\text { people participate in the } \\
\text { needs of the community. }\end{array}$ & $0.66^{*}$ & $0.49^{*}$ \\
\hline & 30 & $\begin{array}{l}\text { Adoption of a specialized } \\
\text { voluntary organization that } \\
\text { contributes to the } \\
\text { organization and planning of } \\
\text { voluntary efforts. }\end{array}$ & $0.67^{*}$ & $0.56^{*}$ \\
\hline & 31 & $\begin{array}{l}\text { Volunteering reduces } \\
\text { students' interest in their } \\
\text { academic achievement. }\end{array}$ & $0.63^{*}$ & $0.59^{*}$ \\
\hline & 32 & $\begin{array}{c}\text { Community institutions take } \\
\text { a positive view of the } \\
\text { volunteer. }\end{array}$ & $0.72^{*}$ & $0.68^{*}$ \\
\hline
\end{tabular}

${ }^{*}$ Function statistically at a level (0.05) 
International Journal of Childhood, Counselling, \& Special Education (CCSE), Volume1, Issue: 2, December: 2020, pp.161-184

It should be noted from table (2) that the values of paragraph correlation coefficients after the nature of volunteering ranged from (0.88-0.49) with its dimension, to (0.73- (0.42 with the overall score of the scale), and that the values of correlation coefficients after paragraphs after the individual's personality and motives ranged from (0.79-0.45) with their dimension, to (0.41-0.65) with The overall degree of the scale, and that the values of paragraph correlation coefficients after the status of volunteer work ranged between (0.74-0.63) with its dimension, and (0.49-0.68) with the overall grade of the scale and all of these values were statistically functioning at the indicative level (0.05), and their correlation coefficient with the overall score of the scale was higher.

Of $(0.30)$, a criterion has been adopted to accept the paragraph with a coefficient of at least (0.30), as indicated by Hattie, 1985, thus accepting all paragraphs of the scale, and therefore the scale is in its final form of (32) paragraphs.

Inter-Correlation values were moreover calculated for the measurements of the slant scale towards volunteering, using the Pearson correlation coefficient, as in table 3 .

Table 3: Values of the trend-forward scale dimensions with the scale as a whole, and interconnection coefficients for scale dimensions.

\begin{tabular}{|c|c|c|c|}
\hline & volunteering. & $\begin{array}{r}\text { Personality and } \\
\text { motivations. }\end{array}$ & volunteerism. \\
\hline $\begin{array}{l}\text { The individual's } \\
\text { personality and } \\
\text { motivations. }\end{array}$ & $0.681^{*}$ & & \\
\hline $\begin{array}{l}\text { The status of } \\
\text { volunteerism. }\end{array}$ & $0.608^{*}$ & $0.698^{*}$ & \\
\hline $\begin{array}{l}\text { Trends towards } \\
\text { volunteerism (as a whole). }\end{array}$ & $0.805^{*}$ & $0.741^{*}$ & $0.793^{*}$ \\
\hline
\end{tabular}

${ }^{*}$ Function statistically at a level $(0.05)$

It is clear from table 3 that the values of interconnection coefficients between the dimensions of the trend-to-voluntary scale ranged from (0.608 to 0.698), and the values of the relationship coefficients between measurements and the scale as a whole range disoriented (0.805-0.741), all of which are statistically significant at the level (0.05), which is an indication of the sincerity of Construction of the scale. 
International Journal of Childhood, Counselling, \& Special Education (CCSE), Volume1, Issue: 2, December: 2020, pp.161-184

Stability of the scale of trends towards volunteerism

To estimate the stability of the internal consistency of the measure of trends towards volunteerism, calculated using the Cronbach's Alpha equation, on the first application data of the 25 students from outside the study sample, and in order to verify the soundness and measurements of the re-replay of the scale; Reapply the scale to the past exploratory test, utilizing the Test- Retest method, with a two-week time difference between the first and second applications, and then calculated using the Pearson correlation coefficient between the first and second applications on the test exploratory, as appeared in table4.

Table 4: Pearson Relationship Coefficient values and inside consistency coefficient values (Alpha Cronbach's) for sub-dimensions of the scale of trends towards volunteerism and the overall scale.

\begin{tabular}{ccc}
\hline Dimension & $\begin{array}{c}\text { Pearson Correlation } \\
\text { Coefficient } \\
\text { The nature of Volunteering }\end{array}$ & $\begin{array}{c}\text { Value of cronbach } \\
\text { Alpha Stability Factor }\end{array}$ \\
$\begin{array}{c}\text { The individual's personality and } \\
\text { Motivations }\end{array}$ & 0.716 & 0.785 \\
The status of Volunteerism & 0.698 & 0.766 \\
Trends towards volunteerism & 0.816 & 0.737 \\
(as a whole) & & 0.830 \\
\hline
\end{tabular}

It is clear from table 4 that the values of Pearson correlation coefficients between the first and second application of the subdimensions of the Voluntary Trends scale ranged from (0.723-0.698), whereas the esteem of the Pearson relationship coefficient between the primary and second application of the entire scale (0.816). It is additionally clear from table 4that the values of internal consistency coefficients for the dimensions of the trend-towards volunteer scale ranged from $(0.785-0.737)$ while the internal consistency coefficient of the total scale $(0.830)$ was a great marker of the soundness of the measurements and the scale as an entirety. Correcting the scale of trends towards volunteerism.

The measure of trends towards volunteerism shall be in its final form of (32) paragraphs distributed in three dimensions, to which the student responds according to a fiveway graduation that includes the following alternatives: (I strongly agree, and given when correcting the scale 5 degrees, I agree and give 4 grades, neutral and given 3 degrees, I do not agree and give two degrees, and I do not agree In the case of positive-trended paragraphs, the 
staging is strongly given and the staging reflects the negative trend. The higher the score, the higher the degree of trends towards volunteering programmers, thus ranging from 32-160 to determine the level of trends towards volunteering among the sample members of the study; their responses were classified to three levels according to the arithmetic average: Low (less than 2.34), average between $(3.66$ - 2.34), high (greater than3.66).

Statistical treatments:

Statistical data processors in this study were carried out using the Social Science Statistical Package (SPSS), as follows:

- To answer the first question of the study, the arithmetic averages and standard deviations of the responses of female students specializing in ASD were calculated on the paragraphs of the scale of trends towards volunteering programs at Jeddah University in Saudi Arabia.

- To answer the second question of the study, the (T) test was used to study the impact of the changing social situation on the trends of female students specializing in ASD towards volunteering programs at Jeddah University according to the scale as a whole and at the level of its sub-dimensions.

- To answer the third question of the study, the test (T) was used to study the impact of the changing economic situation on the trends of female students specializing ASD towards volunteering programs at Jeddah College agreeing to the scale asa

- whole and at the level of its subdimensions.

- To answer the fourth question of the study, one way ANOVA analysis was used to study the impact of the variable academic level on the trends of female students specializing in ASD towards volunteering programs at Jeddah University according to the scale level as a whole and at the level of dimensions hissub.

The results of the study and its discussion

This study aimed to reveal the levels of trends towards volunteering programs among female students specializing ASD at Jeddah University in Saudi Arabia by replying the following questions:

First of all, i'm reaching to have to the results of the first study primary, which stated: "What is the level of trends of female students specializing ASD towards volunteering programs at Jeddah University?

To answer the study's, begin question, the number averages and standard deviations of the responses of female students specializing in ASD were calculated on paragraphs after the nature of volunteering in 
International Journal of Childhood, Counselling, \& Special Education (CCSE), Volume1, Issue: 2, December: 2020, pp.161-184

the measure of trends towards

volunteering programs at Jeddah

University, as shown in table5.

Table 5: Computational midpoints and standard deviations of passages after the nature of volunteering in consider test individuals are positioned downwardly by the math normal.

\begin{tabular}{|c|c|c|c|c|}
\hline Number & Phrase & $\begin{array}{c}\text { Average } \\
\text { arithmetic }\end{array}$ & $\begin{array}{l}\text { Standard } \\
\text { deviation }\end{array}$ & Level \\
\hline 1 & $\begin{array}{l}\text { Volunteering for young } \\
\text { people Brings multiple } \\
\text { skills and experiences }\end{array}$ & 4.62 & 0.50 & High \\
\hline 2 & $\begin{array}{l}\text { Volunteering strengthens } \\
\text { feelings of belonging and } \\
\text { national and religious loyalty } \\
\text { among university youth }\end{array}$ & 4.55 & 0.51 & High \\
\hline 3 & $\begin{array}{l}\text { Volunteering allows } \\
\text { opportunities for young } \\
\text { people to express themselves } \\
\text { and their energies }\end{array}$ & 4.52 & 0.59 & High \\
\hline 4 & $\begin{array}{c}\text { I encourage my } \\
\text { classmates to participate in } \\
\text { volunteering }\end{array}$ & 4.47 & 0.56 & High \\
\hline 5 & $\begin{array}{c}\text { Planting Islamic principles } \\
\text { and values that encourage } \\
\text { volunteering }\end{array}$ & 4.46 & 0.63 & High \\
\hline 6 & $\begin{array}{c}\text { Using social media } \\
\text { To encourage }\end{array}$ & 4.45 & 0.55 & High \\
\hline 7 & $\begin{array}{l}\text { Volunteerism Volunteering } \\
\text { institutions contribute to } \\
\text { deepening social solidarity } \\
\text { among members of society }\end{array}$ & 4.37 & 1.10 & High \\
\hline 8 & $\begin{array}{l}\text { Intensifying lectures and } \\
\text { seminars on the importance } \\
\text { of volunteering and adopting } \\
\text { and refining the } \\
\text { Personality of the university } \\
\text { student }\end{array}$ & 4.19 & 0.78 & High \\
\hline 9 & $\begin{array}{l}\text { Community organizations } \\
\text { adopt effective volunteer } \\
\text { programs }\end{array}$ & 4.13 & 0.66 & High \\
\hline
\end{tabular}


International Journal of Childhood, Counselling, \& Special Education (CCSE), Volume1, Issue: 2, December: 2020, pp.161-184

10

$$
\begin{aligned}
& \text { Volunteering does not } \\
& \text { require expertise and } \\
& \text { specialization }
\end{aligned}
$$

I've received proper guidance

and guidance during

volunteering.

It is important to volunteer, including married students.

From the difficulties of volunteering in relation to

society the economic,

political and social conditions

The volunteer communicates

with the foundation's staff on an ongoing basis

Study programs include the concepts of volunteering

Volunteering is a heavy burden.

4.11

4.02

0.96

3.86

0.84

High

It is obvious from table 5 that the mathematical midpoints of phrases after the nature of volunteer work in the measure of trends towards volunteering programs among female students specializing in ASD at Jeddah University in Saudi Arabia ranged from (2.19) to the phrase (volunteering is a heavy burden to avoid doing). Most of the phrases came at the (high) level of attribute presence, with the exception of one phrase that occurred at the low level of the presence of the attribute, and the general level of the dimension of the nature of volunteering (high).

Computational midpoints and standard deviations of the reactions of female students specializing in ASD were calculated on sections after the individual's identity and motivations in the measure of trends towards volunteering programs at Jeddah University, as shown in table (6). 
International Journal of Childhood, Counselling, \& Special Education (CCSE), Volume1, Issue: 2, December: 2020, pp.161-184

Table 6: Computational averages and standard deviations of paragraphs after the individual's personality and motivations in the study sample members are ranked downwardly by the arithmetic

\begin{tabular}{|c|c|c|c|c|}
\hline Number & Phrase & $\begin{array}{c}\text { Average } \\
\text { arithmetic }\end{array}$ & $\begin{array}{l}\text { Standard } \\
\text { deviation }\end{array}$ & level \\
\hline 1 & $\begin{array}{l}\text { I feel Albashery when I help } \\
\text { others by volunteering. }\end{array}$ & 4.73 & 0.47 & High \\
\hline 2 & $\begin{array}{l}\text { Volunteering helps me } \\
\text { develop my professional } \\
\text { abilities in the future. }\end{array}$ & 4.64 & 0.52 & High \\
\hline 3 & $\begin{array}{l}\text { Volunteering refines and } \\
\text { Develops my personality. }\end{array}$ & 4.61 & 0.52 & High \\
\hline 4 & $\begin{array}{l}\text { Volunteering develops a sense } \\
\text { of self and responsibility }\end{array}$ & 4.58 & 0.52 & High \\
\hline 5 & $\begin{array}{l}\text { I feel good when I find } \\
\text { appreciation as a result of my } \\
\text { volunteering efforts. }\end{array}$ & 4.53 & 0.61 & High \\
\hline 6 & $\begin{array}{l}\text { Volunteering makes me } \\
\text { Sympathize with the suffering } \\
\text { of others. }\end{array}$ & 4.49 & 0.63 & High \\
\hline 7 & $\begin{array}{l}\text { Volunteering achieves the } \\
\text { satisfaction of an individual's } \\
\text { psychological needs }\end{array}$ & 4.37 & 0.75 & High \\
\hline 8 & $\begin{array}{l}\text { Volunteering gives me the } \\
\text { opportunity to freely express } \\
\text { my opinions and ideas. }\end{array}$ & 4.31 & 0.75 & High \\
\hline 9 & I use my free time to volunteer. & 4.19 & 0.83 & High \\
\hline \multicolumn{2}{|c|}{$\begin{array}{l}\text { Individual personality and motivation (as a } \\
\text { whole) }\end{array}$} & 4.50 & 0.39 & High \\
\hline
\end{tabular}

It is clear from Table 6 that the mathematical averages of phrases after the individual's personality and motivations in the measure of trends towards volunteering programs among female students specializing in ASD at Jeddah University in Saudi Arabia ranged from (4.19) to the phrase "Take advantage of my free time in volunteering" to (4.73) for the phrase (I feel my Albasheryity when I help others through volunteering), all the phrases came at the (high) level of the presence of the attribute, and the general level of individual personality and motivation(high).

Computational averages and 
International Journal of Childhood, Counselling, \& Special Education (CCSE), Volume1, Issue: 2, December: 2020, pp.161-184

standard deviations of responses of female students specializing in ASD were also calculated on paragraphs after the place of volunteering in the scale of trends towards volunteering programs at Jeddah University, as shown in table (7).

Table 7: Computational averages and standard deviations of paragraphs after the status of volunteering among study sample members are ranked downwardly by the arithmetic average.

\begin{tabular}{|c|c|c|c|c|}
\hline Number & Phrase & $\begin{array}{l}\text { Average } \\
\text { arithmetic }\end{array}$ & $\begin{array}{l}\text { Standard } \\
\text { deviation }\end{array}$ & level \\
\hline 1 & $\begin{array}{l}\text { Volunteering strengthens feelings of } \\
\text { belonging and national and religious loyalty } \\
\text { among university youth }\end{array}$ & 4.55 & 0.51 & High \\
\hline 2 & $\begin{array}{l}\text { Volunteering helps young people participate } \\
\text { in the needs of the community }\end{array}$ & 4.54 & 0.54 & High \\
\hline 3 & $\begin{array}{l}\text { Volunteering for young people achieves an } \\
\text { important skill in the ability to plan and solve } \\
\text { problems }\end{array}$ & 4.51 & 0.54 & High \\
\hline 4 & $\begin{array}{c}\text { Adoption of a specialized voluntary } \\
\text { organization that contributes to the } \\
\text { organization and planning of voluntary } \\
\text { efforts }\end{array}$ & 4.42 & 0.66 & High \\
\hline 5 & $\begin{array}{l}\text { Volunteering institutions contribute to } \\
\text { deepening solidarity within society }\end{array}$ & 4.35 & 0.59 & High \\
\hline 6 & $\begin{array}{l}\text { Community institutions take a } \\
\text { positive view of the volunteer }\end{array}$ & 4.24 & 0.74 & High \\
\hline 7 & $\begin{array}{l}\text { Volunteering reduces students' interest in } \\
\text { their academic achievement }\end{array}$ & 2.27 & 1.28 & Low \\
\hline \multicolumn{2}{|c|}{ The status of volunteerism (as a whole) } & 4.13 & 0.39 & High \\
\hline \multicolumn{2}{|c|}{$\begin{array}{l}\text { Trends towards volunteering programs at Jeddah } \\
\text { University (as a whole) }\end{array}$} & 4.12 & 0.35 & High \\
\hline
\end{tabular}

It is clear from the table7 that the mathematical averages of phrases after the place of volunteer work in the measure of trends towards volunteering programs among female students specializing in ASD at Jeddah University in Saudi Arabia ranged from (2.27) to the phrase "volunteerism reduces students" interest in their academic achievement. And (4.55) for the phrase (volunteer work strengthens feelings of belonging and national and religious loyalty among university youth), most of the phrases came at the (high) level of the presence of the attribute, except for one phrase that occurred at the low level of the presence of the attribute, and the general level of the remoteness of the status of volunteering (High). It is also clear from table 7 that the general trend towards volunteering programs at Jeddah University among female students specializing in ASD at 
International Journal of Childhood, Counselling, \& Special Education (CCSE), Volume1, Issue: 2, December: 2020, pp.161-184

Jeddah University has been high.

Second: The results of the second study question, which stated: "Are there statistically significant differences at the level of indication $(\boldsymbol{\alpha}=0.05)$ in the average trends of female students specializing in ASD towards volunteering programs at Jeddah University due to the change in social status?
To answer the question of the second study, the arithmetic averages and standard deviations of the responses of female students specializing in ASD were calculated on the paragraphs of the scale of trends towards volunteering programs at Jeddah University according to the change of social status, and the test $(\mathrm{T})$ was used. To examine the indications of differences in mathematical averages, as in table (8).

Table 8: Results of the Test $(T)$ to examine the indications of differences in the mathematical averages of the trends of female students specializing in ASD towards volunteering programs at Jeddah University depending on the change in social status

\begin{tabular}{|c|c|c|c|c|c|c|c|}
\hline Dimension & $\begin{array}{l}\text { Social } \\
\text { status }\end{array}$ & Number & $\begin{array}{l}\text { Average } \\
\text { Arithmetic }\end{array}$ & $\begin{array}{l}\text { Deviation } \\
\text { Normative }\end{array}$ & $\begin{array}{l}\text { Value } \\
\text { (t) }\end{array}$ & $\begin{array}{l}\text { Degrees } \\
\text { Freedom }\end{array}$ & $\begin{array}{l}\text { The } \\
\text { significance } \\
\text { Statistics }\end{array}$ \\
\hline The nature & single & 125 & 3.90 & 0.38 & - & 152 & 0.200 \\
\hline Of volunteering & Married & 29 & 4.01 & 0.51 & $\begin{array}{l}1.28 \\
7\end{array}$ & & \\
\hline The individual' & single & 125 & 4.48 & 0.40 & 1.20 & 152 & 0.230 \\
\hline $\begin{array}{l}\text { s personality } \\
\text { and } \\
\text { motivations }\end{array}$ & Married & 29 & 4.57 & 0.32 & 6 & & \\
\hline $\begin{array}{l}\text { The status } \\
\text { of }\end{array}$ & single & 125 & 4.11 & 0.38 & 1.32 & 152 & 0.188 \\
\hline volunteerism & Married & 29 & 4.21 & 0.45 & 3 & & \\
\hline $\begin{array}{l}\text { Trends } \\
\text { towards } \\
\text { volunteer } \\
\mathrm{i}\end{array}$ & single & 125 & 4.11 & 0.34 & $\begin{array}{l}- \\
1.39 \\
1\end{array}$ & 152 & 0.166 \\
\hline $\begin{array}{l}\text { ng programs } \\
\text { at Jeddah } \\
\text { University } \\
\text { (as } \\
\text { awhole) }\end{array}$ & Marrie d & 29 & 4.21 & 0.41 & & & \\
\hline
\end{tabular}

${ }^{*}$ Function statistically at the indication level (0.05). 
International Journal of Childhood, Counselling, \& Special Education (CCSE), Volume1, Issue: 2, December: 2020, pp.161-184

It is evident from table (8) that there are no statistically significant differences at the level of indication $(\alpha=0.05)$ in the scientific midpoints of trends of female students specializing in ASD towards volunteering programs at Jeddah University depending on the change of social status at the level of the scale as a whole and at the level of dimensions his sub.

Third: The results of the third study question, which stated: Are there statistically significant differences at the level of indication $(\boldsymbol{\alpha}=0.05)$ in the average trends of female students specializing in ASD towards volunteering programs at Jeddah University due to the change in economic situation?

To answer the study's third question, the arithmetic averages and standard deviations of the reactions of female students specializing in ASD were calculated on the paragraphs of the scale of trends towards volunteering programs at Jeddah University according to the change of economic situation, and the test $(T)$ was used. To examine the indications of differences in mathematical averages, as in table (9).

Table 9: Results of the Test $(T)$ to examine the indications of differences in the mathematical averages of the trends of female students specializing in ASD towards volunteering programs at Jeddah

\begin{tabular}{|c|c|c|c|c|c|c|c|}
\hline Dimension & $\begin{array}{l}\text { Social } \\
\text { status }\end{array}$ & Number & $\begin{array}{l}\text { Average } \\
\text { Arithmetic }\end{array}$ & $\begin{array}{l}\text { Deviation } \\
\text { Normative }\end{array}$ & Value $(\mathrm{t})$ & $\begin{array}{l}\text { Degrees } \\
\text { Freedom }\end{array}$ & $\begin{array}{l}\text { The signifi } \\
\text { cance Statis tics }\end{array}$ \\
\hline The nature of & Average & 62 & 3.98 & 0.48 & $\begin{array}{l}1.55 \\
1\end{array}$ & 152 & 0.123 \\
\hline $\begin{array}{l}\text { volunteer } \\
\text { ing }\end{array}$ & Excellent & 92 & 3.88 & 0.35 & & & \\
\hline The individua & Average & 62 & 4.44 & 0.41 & -1.55 & 152 & 0.122 \\
\hline $\begin{array}{l}\text { l's personali } \\
\text { ty and } \\
\text { motivatio } \\
\text { ns }\end{array}$ & $\begin{array}{l}\text { Excell } \\
\text { ent }\end{array}$ & 92 & 4.54 & 0.37 & 6 & & \\
\hline The status of & Average & 62 & 4.12 & 0.40 & 0.14 & 152 & 0.889 \\
\hline $\begin{array}{l}\text { volunteer } \\
\text { ism }\end{array}$ & Excellent & 92 & 4.13 & 0.39 & 0 & & \\
\hline $\begin{array}{l}\text { Trends } \\
\text { towards }\end{array}$ & $\begin{array}{l}\text { Averag } \\
\mathrm{e}\end{array}$ & 62 & 4.15 & 0.41 & $\begin{array}{l}0.49 \\
0\end{array}$ & 152 & 0.625 \\
\hline
\end{tabular}


International Journal of Childhood, Counselling, \& Special Education (CCSE), Volume1, Issue: 2, December: 2020, pp.161-184

\begin{tabular}{lllll} 
ing programs & $\begin{array}{l}\text { Excell } \\
\text { ent }\end{array}$ & 92 & 4.12 & 0.31 \\
at Jeddah & & & & \\
University & & & & \\
$\begin{array}{l}\text { (as a } \\
\text { whole) }\end{array}$ & & & & \\
\hline
\end{tabular}

${ }^{*}$ Function statistically at the indication level (0.05).

It is evident from table (9) indication $(\boldsymbol{\alpha}=0.05)$ in the average trends of female students specializing in ASD towards volunteering programs at Jeddah University due to the change in scholarly level?

To reply the study's fourth students specializing in ASD towards volunteering programs at Jeddah University depending on the change in the economic situation at the level of the scale as a whole and at the level of dimensions his sub.

Fourth: The results of the fourth study question, which states: Are there statistically significant differences at the level of address, the arithmetic midpoints and standard deviations of the reactions of female students specializing in ASD were calculated on the scale of trends towards volunteering programs at Jeddah University according to the academic level variable, as appeared in table (10).

Table (10): Computational midpoints and standard deviations of trends towards volunteering programs at Jeddah University are due to their overall allowances and sub-dimensions in female students specializing in ASD according to academic level.

\begin{tabular}{lllllll}
\hline Variable & $\begin{array}{l}\text { Variable } \\
\text { levels }\end{array}$ & Statistik & $\begin{array}{l}\text { The nature of } \\
\text { volunteer ing }\end{array}$ & $\begin{array}{l}\text { The individu } \\
\text { al's personal } \\
\text { ity and } \\
\text { motivations }\end{array}$ & $\begin{array}{l}\text { The status of } \\
\text { volunteerism }\end{array}$ & $\begin{array}{l}\text { Trends } \\
\text { towards } \\
\text { volunteering } \\
\text { programs at } \\
\text { Jeddah } \\
\text { University (asa } \\
\text { whole) }\end{array}$ \\
\hline $\begin{array}{l}\text { Academi } \\
\text { clevel }\end{array}$ & $\begin{array}{l}\text { Level } \\
6 \quad \text { and } \\
\text { below }\end{array}$ & $\begin{array}{l}\text { Average } \\
\text { arithmetic }\end{array}$ & 4.04 & 4.53 & 4.13 & 4.20 \\
\hline
\end{tabular}


International Journal of Childhood, Counselling, \& Special Education (CCSE), Volume1, Issue: 2, December: 2020, pp.161-184

The most important results and recommendations

- The trends of the students of the Special Education Department specializing in ASD came high.

- There are no factually noteworthy contrasts at the level of sign $(\alpha=0.05)$ in the mathematical midpoints of trends of patterns students specializing in ASD towards volunteering programs at Jeddah University depending on the change in the social status and the understudy at the level and the social status of the student at the level of the scale as a a entire whole and at the level of its sub dimensional dimensions.

- This result is coherent in agreement with the principles of Saudi and Islamic society and the patterns of Vision 2030. The lessons of the Islamic religion and the quality of religious disorientation among the students and the positive trend towards volunteerism. The main motivation for positive results towards volunteering from the point of view of students specializing in ASD is to acquire new experiences and skills and desire to help and feel satisfied and psychological comfort and self-affirmation where volunteering achieves a sense of comfort and satisfaction and increased outcome Knowledge for providing help and assistance. The positive results of jeddah university students can be explained for their interest in this age group in the social aspects and their development. Study Community as a Study (Hernández, 2017; Caroline and Others, 2014; Gig, 2013).

- The researcher hopes that this study will be a scientific addition that opens the horizons of researchers to the importance of volunteering.

- The need to hold training courses and workshops for female students to highlight the importance of volunteering.

- The establishment of volunteer units to guide female students to volunteer in appropriate fields in the Faculty of Education for Girls.

- Instilling a culture of volunteerism in public education and introducing courses to volunteer through courses.

- Activating the role of the media and intensifying interest in volunteering

\section{References}

Autism Society of America (2018). What is Autism? Retrieved from https://www.autismsociety.org/what-is

Abu Al-Nasr, Medhat (2015). visions for the development of volunteer work in the Arab world Alexandria: 
International Journal of Childhood, Counselling, \& Special Education (CCSE), Volume1, Issue: 2, December: 2020, pp.161-184

The Modern University Library.

Al-Bakr, Assem, Nabulsi, Hana, AlAdayleh, and Lubna (2017). Obstacles to volunteer work among youth at the University of Jordan: a sociological study Human and social sciences studies, 44, Appendix, 2017 Albeshry, Sami Bin Shtian Darwish (2019), Saudi youth's attitudes towards volunteerism in light of Saudi Arabia Vision 2030, Egyptian Society of Social Workers, 1, 61.

Al-Dawish, Abdulaziz. (2015). The role of academic leaders at Imam Muhammad bin Saud Islamic University in activating volunteer work, Journal of Educational Sciences. Second issue, pp. 366-431, Imam Muhammad bin Saud Islamic University, Riyadh.

Al-Harbi,Hamed Salem (2000). The rules of voluntary service " Educational vision (Islamic), research and papers of the first scientific conference for voluntary services in Saudi Arabia, held at um al-Qura University, Mecca .

Al-Mazin, Suleiman Hassan Musa (2015), Students' attitudes towards volunteering in the universities of Gaza governorates and ways to activate it in light of some changes.

Al-Mutawa, Abdullah bin Saud bin Suleiman, (2019). Areas of volunteer work and its educational dimensions in the Vision of Saudi Arabia 2030, Analytical Study, Blonde Magazine Saudi Arabia, p.89-125.
Al-Qahtani, Ibrahim Bin Faraj (2019). The reality of the department of volunteer work at Imam Mohammed Bin Saud Islamic University from the point of view of students of the Faculty of Social Sciences, Journal of Educational and Psychological Sciences, 3(28), 13-40.

Al-Zayoud, Ismail, Al-Kubaisi, Sanaa (2014). Attitudes of Petra University students towards volunteer work in Jordan, Jordanian Journal of Social Sciences, 7(3), 438.

Heresh, Khaled, Jabr, Nahed (2012), Journal of the Union of Arab Universities for Research in Higher Education, 33 (1),499-524.

Hattie, J. (1985). Methodology review: assessing unidimensionality of tests and ltenls. Applied Psychological measurement ,9(2),139-164,

https://doi.org/10.1177/0146621685009 00204

Hoerining, Beate. (2017). The importantance of Volunteer work for successful children s and Adult literacy programs in US public Libraries - aview from outside Berline school of Library and information science, Berlin, Germany P.109

Gagee (2013). Analysis of the Volunteer function Inventary and Leisare constraints models pennsylunania state University. International Journal of Volumteer Administration, 15(3), 50-66. 
International Journal of Childhood, Counselling, \& Special Education (CCSE), Volume1, Issue: 2, December: 2020, pp.161-184

Khaddam, Hamed (2013). Trends of University Youth towards Volunteering, Ajloun University College, Journal of Educational Sciences, Jordan, Amman.

Kunda, Salma (2018). Social marketing of volunteering through social networking sites (read on the Facebook pages of some Algerian charities, Algeria, University of Setif, Algeria.

John Willson. (2016). Volunteering Annual Review of Sociology Retrieved 7-11-2016

Mahdi, Astabarq (2019). The role of the university in promoting the culture of volunteerism among students (Al-Mustansiriyah University model). Research Journal of the 26th Issue, University of Baghdad.

Return, Ahmed (2014). Measurement and evaluation in the teaching process, Irbid, Daral-Amal

Riot, C, Cuskelly, G, Christopher, Zakus, Dwight (2014), Volunteer roles, involvement and commitment in voluntary sport organizations. Sport in Society. Cultures Commerce, Media, oltics. Volume17(1), 116-133, https://doi.org/10.1080/17430437.2013. 828902

Sawalha, Aounia (2014). Directions of the principals of public and private schools in Amman governorate towards the program of learning difficulties in the resource room magazine Islamic University for Educational and Islamic Studies, Gaza, M22, p. 3 p.112-146.

The Holy Quran, Sura al-Baqaa alAyat158-184

The Holy Quran, Sura al-Hajj alAya77.
Al-Zahrani, Abdullah Muhammad (2003). Characteristics of the youth stage and the role of charitable work in meeting the psychological, social and educational needs of youth as perceived by young people working in charitable societies in the Kingdom of Saudi Arabia. 